Chung, Jennifer, PIS A and GlobalEducation Policy - Understanding Finland's Success and Influence. Leiden: Koninklijke Brill NV, 2019.

Izobraževanje v kontekstu globalizacije ne zaostaja za drugimi javnopolitičnimi področji in se prav zaradi nje precej spreminja. Posledica globalizacije je med drugimi mobilizacija, ki pa jo je moč zaznati tudi v razvoju izobraževanja in izobraževalnih politik, saj prehajanje idej in značilnosti iz enega izobraževalnega sistema v drugega še nikoli ni bilo tako intenzivno. Mobilizacijo omogočajo primerjave izobraževalnih sistemov in javnih izobraževalnih politik, ena izmed takšnih primerjav pa je tudi raziskava PISA. Raziskavo PISA vodi OECD, ki države razvršča na podlagi rezultatov in uspešnosti petnajstletnikov na področju naravoslovja, matematike in branja, in sicer na podlagi dosežkov pri različnih nalogah, $s$ katerimi preverja uporabo $\mathrm{v}$ šoli pridobljenega znanja $\mathrm{v}$ različnih problemsko zasnovanih situacijah.

Knjiga PISA and GlobalEducation Policy - Understanding Finland's Success and Influence dokazuje, da je raziskava PISA veliko več kot le pridobivanje podatkov o uspešnosti izobraževalnih sistemov in razvrščanje držav. Njen vpliv se širi tudi na politična polja in gospodarstvo. Rezultati prvega cikla raziskave leta 2000 so »poveličali« Finsko, ki se je izmed vseh sodelujočih OECD držav odrezala najbolje, in jo predstavili širšemu svetu kot vzor izobraževalnega sistema. Začelo se je množično romanje pedagogov, strokovnjakov in snovalcev javnih politik na Finsko z namenom iskanja odgovora na vprašanje, kako jim uspe. Tudi Jennifer Chung si je v ocenjevani knjigi postavljala isto vprašanje.

Avtorica je knjigo razdelila na ro poglavij, kjer se v začetku osredotoči na finsko zgodovino, finski izobraževalni sistem - njegove prednosti in slabosti, na OECD in raziskavo PISA sámo po sebi ter problematiko prenosa javnih politik. V drugem delu pa različni strokovnjaki (npr. dva bivša finska ministra za izobraževanje, učitelji, ravnatelji in zaposleni na OECD) predstavijo svoje izkušnje, znanje in poglede na raziskavo PISA, izobraževalne sisteme in prenose idej iz finskega izobraževalnega sistema v druge.

V začetku knjige avtorica predstavi raziskavo PISA in njen širši pomen v globalnem kontekstu. Raziskava PISA je namreč veliko več kot le razvrščanje izobraževalnih sistemov sodelujočih držav. Rezultati raziskave PISA oblikujejo standarde, norme in načine ocenjevanja ter spodbujajo države k nenehni (samo)evalvaciji in napredku. Poseben poudarek v knjigi je namenjen povezanosti izobraževanja in gospodarstva. Predpostavlja se namreč, da države z boljšim ekonomskim standardom vlagajo več sredstev v razvoj izobraževanja oziroma da bolj kakovostno izobraževanje 
pozitivno pripomore $\mathrm{k}$ razvoju gospodarstva. Ta začaran krog predstavlja predpostavko, da razvoj izobraževalne politike odraža gospodarstvo države in posledično njen pomen in vpliv na globalni ravni. Pri tem pomembno vlogo odigrajo mednarodne primerjave, saj državam kažejo smernice razvoja, področja možnih izboljšav in primere drugih držav. Vsekakor pa je treba na mednarodno raziskavo, kot je PISA, gledati tudi kritično, saj narekuje standarde izobraževalne politike in učenja po svojih vrednotah in smernicah, $s$ čimer pa lahko zanemarja pomen nacionalnih potreb in vlogo nacionalnih držav pri oblikovanju nacionalnih izobraževalnih politik. Prvo poglavje se zaključi z oceno, da imajo mednarodne raziskave znanja, vključno s PISA, veliko vlogo pri razvoju izobraževanja in globalnega sveta nasploh, zato tako množičen odziv na rezultate in izreden interes za preučevanje finskega izobraževalnega sistema ni presenečenje.

Avtorica nadaljuje s sliko razvoja finske zgodovine, torej od prvih naseljencev do velike krize v 90 . letih prejšnjega stoletja. Opiše trpko zgodovino ljudstva, ki živi v težkih naravnih in družbenih razmerah. Vremenski pojavi Finski ne prizanašajo, hkrati pa so tudi družbene razmere terjale svojo ceno. Finska je bila 600 let namreč pod švedsko oblastjo, kasneje pa je postala še bojišče med Švedi in Rusi in posledično pristala pod rusko oblastjo. Leta 1917 se je Finska osamosvojila ter izvolila prvega demokratično izvoljenega socialističnega predsednika vlade. Zgodovinski razvoj je pustil hude posledice - revščino, brezposelnost in razslojenost družbe na »bele in rdeče «, kar je postalo povod za državljansko vojno, iz katere je Finska prišla stabilnejša in močnejša. To je bila dobra popotnica za drugo svetovno vojno. Velik pokazatelj urejenosti in karakterja države je dejstvo, da je Finska prva poravnala svoj denarni dolg zaradi vojne in od takrat naprej razvijala različne socialne politike, od pokojninske do izobraževalne, ter $s$ tem postala vzor mnogim državam. Kasneje, po letu 1990, je Finsko udarila nova kriza, tokrat finančna, zaradi zaprtja mej z Rusijo. Finska se je tako usmerila $\mathrm{v}$ izboljšanje odnosov $\mathrm{z}$ zahodom in vstopila $\mathrm{v}$ EU. Vse to dela finsko državo finsko in vpliva na ureditev, organiziranost ter način delovanja tako države kot prebivalcev. Sami temu pravijo sisu, kar je izraz, ki zajema njihov edinstveni jezik, politiko, religijo, družbo, torej vse, kar je edinstvenega na Finskem in tamkajšnjih prebivalcih. Avtorica trdi, da je zgodovina oblikovala družbo v eno izmed boljših na svetu, hkrati tudi religija ni bila v nasprotju z državo, temveč sta skupaj kazali pot razvoja. Tako finska politika kot religija namreč ideološko podpirata egalitarizem, enakost med spoloma, močne socialne politike in stremita $\mathrm{k}$ izboljšanju položaja vsakega posameznika.

Takšen razplet zgodovinskih in družbenih dogodkov je na Finskem omogočil oblikovanje kakovostnega izobraževalnega sistema že od 60 . 
let prejšnjega stoletja dalje. Razvoj izobraževanja na Finskem je bil počasen, spremembe pa premišljene in načrtovane. Avtorica v knjigi izpostavlja tudi najpomembnejše komponente finskega izobraževalnega sistema. Finski šolski sistem temelji na egalitarizmu: vsak učenec ima enake možnosti dostopa do izobraževanja vse od osnovne šole do univerze in naprej, na Finskem so enotne šole za vse učence, zelo malo je zasebnih šol, učenci v šoli niso ločeni po spolu, tudi učenci s posebnimi potrebami so vključeni v redne šole. Učenci so $\mathrm{v}$ šolah relativno malo časa, povprečno 30 ur tedensko, saj se Finci zavedajo pomembnosti prostega časa in tudi zimskih razmer, ko se noč začenja precej zgodaj. Izobraževalni sistem je zelo decentraliziran. Država nad učitelji ne izvaja nadzora, osnovni kurikulum je postavljen s strani države, ki pa ga dopolnjuje lokalna oblast, šola, v največji meri pa učitelji sami glede na potrebe učencev. Sami določajo tudi metode in pristope $v$ razredu, način ocenjevanja, izbirajo gradivo; pri tem niso pretirano nadzorovani, obremenjeni z birokracijo in inšpekcijskimi nadzori s strani oblasti. Izobraževalni sistem na ta način lahko deluje $s$ sposobnimi in dobro usposobljenimi učitelji ter pedagoškimi delavci. Avtorica v knjigi nameni dobršen del opisu izobraževanja učiteljev, ki je zelo zahtevno. Univerza sprejme le najboljše dijake in dijakinje in stremi $\mathrm{k}$ temu, da lahko učitelji postanejo le najbolj sposobni pedagogi, ki omogočajo vrhunsko izobraževanje otrok. Izobrazba ima v finski družbi velik pomen, biti učitelj je častno, poklic je spoštovan in se glede na simbolni družbeni položaj uvršča med zdravnike in pravnike.

$\mathrm{V}$ drugem delu knjige se avtorica obrača $\mathrm{k}$ bolj politološkemu pogledu na raziskavo PISA in opisuje vlogo finskega načina izobraževanja $v$ svetu. $Z$ rezultati raziskave PISA 2000 je bilo konec ugibanj, katera država ima najboljše izobraževanje, saj raziskava PISA ne preverja kurikularnih znanj, temveč uporabo $\mathrm{v}$ šoli pridobljenih znanj $\mathrm{v}$ različnih problemsko zasnovanih kontekstih. Raziskava PISA ponudi podatke, države pa jih lahko interpretirajo same. OECD, upoštevajoč rezultate raziskave PISA, državam ponudi tudi smernice in priporočila, vendar države upoštevajo le tisto, kar same želijo. Države se lahko torej odločijo za reforme ali manjše popravke, lahko prenesejo politike iz drugih sistemov ali pa smernic in priporočil enostavno ne upoštevajo. Pri reformah, izhajajočih iz rezultatov raziskave PISA, avtorica na podlagi teoretičnih pristopov opozarja, da se države navadno osredotočijo na izboljšanje poučevanja učencev s slabšimi učnimi sposobnostmi, a dokazano je, da se lahko osredotočijo na oboje, boljše in slabše učence, kar lahko na ravni izobraževalnega sistema kot celote prinese velik napredek. Tekom knjige poudarja še slabosti hitrih popravkov, da bi zadovoljili nadaljnje visoke uvrstitve na mednarodnih lestvicah. Tovrstni pristop je namreč nepremišljen, 
narejen brez analiz in brez zavedanja o posledicah. Tudi prenosi javnih politik iz drugih držav imajo svoje slabosti, kot tudi prednosti. Avtorica v petem poglavju predstavi razsežnosti prenosa javnih politik, od teoretičnih pristopov do praks tekom zgodovine. Opisuje različne pristope $k$ prenosu javnih politik, smernice in tudi korake, ki so v pomoč pri odločitvi za teme, in sam proces prenosa v praksi. Vsebina poglavja daje bralcem vpogled v kompleksnost odločitve za prenos javnih politik in posledice, ki jih lahko le-ta nosi. Opozarja tudi, da izobraževanje in izobraževalne politike niso imuni na politične igre in so lahko izrabljeni za navajanje »laži« ter krepitev politične moči. Avtorica izpostavi primer Japonske, kjer so mediji prirejali rezultate raziskave PISA, da bi širša javnost podprla politične odločitve. Primer pa ni osamljen, zato je avtorica v knjigi predstavila paleto odzivov na rezultate raziskave PISA, zgrešene prenose javnih politik in tudi nekatere uspešne. Vsak zase je vreden vpogleda in preučevanja, učenja iz napak in zgodb o uspehu.

In končno, kaj je skrivnost Fincev, da dosegajo tako dobre rezultate? Kot pravi ena izmed intervjuvanih učiteljic: skrivnosti ni. Finska je skupek mnogih komponent in lastnosti, ki ustrezajo merilom raziskave PISA. To lahko trdimo, saj v drugih mednarodnih raziskavah znanja ni uvrščena na najvišja, toda še vedno na visoka mesta. Ne glede na to je Finska edinstven primer kot država, družba ter izobraževalni sistem, predstavljena knjiga pa nam razkriva poglobljen vpogled $\mathrm{v}$ vsak posamezen košček tega sistema, ki skupaj tvorijo nedvomno dovršeno celoto, ta pa predstavlja zgled izobraževalnim sistemom širom sveta.

Knjiga je dobra popotnica političnim odločevalcem, saj ponuja na enem mestu zbrane teoretične pristope in dosedanje izkušnje glede prenosa javnih politik; prav tako politologom in strokovnjakom na področju pedagogike, ki lahko preko knjige spoznavajo smernice poučevanja na Finskem ter ostale pedagoške pristope, pa tudi vsem, ki jih zanimajo finska družba, zgodovina in njihov izobraževalni sistem. Vse zgoraj opisano je le delček nadvse zanimive in bogate vsebine knjige, ki je rezultat dolgoletnega dela in raziskovanja avtorice na področju nordijskih izobraževalnih sistemov. Knjiga prinaša nove razsežnosti politološkega znanja, pa tudi splošne razgledanosti in zanimivih dejstev, ter pripomore $\mathrm{k}$ drugačnemu pogledu na vsakodnevna dogajanja ter razvoj sveta v globalnem pomenu.

\section{Urška Koritnik}

